\title{
Design and Analysis of ANN-Based MPPT for Hybrid System
}

\author{
M. Rajeshwari ${ }^{1} \mid$ Dr. K Ranjith Kumar ${ }^{1}$
}

${ }^{1}$ Department of Electrical and Electronics Engineering, Government college of Technology, Coimbatore, India.

\section{To Cite this Article}

M. Rajeshwari and Dr. K Ranjith Kumar, "Design and Analysis of ANN-Based MPPT for Hybrid System", International Journal for Modern Trends in Science and Technology, 6(8): 206-212, 2020.

\section{Article Info}

Received on 17-July-2020, Revised on 02-August-2020, Accepted on 07-August-2020, Published on 16-August-2020.

\section{ABSTRACT}

In this paper, artificial neural network (ANN) Based MPPT for hybrid Solar and Wind system is designed and analyzed for the standalone application. The Power generation from the PV and wind systems will depend on the availability of solar irradiation and wind velocity respectively. The extraction of maximum power from both sources is the main target in the hybrid renewable energy system. The performance of the ANN based MPPT is analyzed by comparing with the conventional P\&O MPPT. A 570W PV system and 500W Wind system is considered with Boost Converter topology for the design of the hybrid system and it is simulated in MATLAB/Simulink environment to analyze the performance of ANN MPPT.

KEYWORDS: PV System, Wind System, Hybrid System, Boost converter, P\&O and ANN MPPT

\section{INTRODUCTION}

Due to the critical condition of industrial fuels which include oil, gas and others, the development of renewable energy sources is continuously improving. This is the reason why renewable energy sources have become more important these days. Few other reasons include advantages like abundant availability in nature, eco-friendly and recyclable. Many renewable energy sources like solar, wind, hydro and tidal are there. Among these renewable sources solar and wind energy are the world's fastest growing energy resources. With no emission of pollutants, energy conversion is done through wind and PV cells [1]. From the literature solar and the wind are the most promising renewable energy sources and its grid-tied installed capacity in India is $57 \%$ of wind source and 19\% of PV source as of Feb. 28th, 2017[2].

The efficiency of photovoltaic (PV) panel is affected by the changing irradiation and temperature. So it is important to implement maximum power point tracking (MPPT) for PV system [3].The power generation from the Wind system will depend on the availability of Wind velocity. The variable speed turbine system is more advantageous than fixed speed turbine system due to high efficiency, enhanced power quality and MPPT [4].

The power generation from the PV and wind systems will depend on the availability of solar irradiation and wind velocity respectively. Due to the high penetration of renewable sources in nature, the power developed from these sources leads to intermittent and uncertain voltage. Hence, to smoothen out these fluctuations different renewable energy sources are to be integrated together with the help of power electronic converters to form a hybrid system and it requires a maximum power point tracking (MPPT) control algorithm to track the maximum available power from the high penetrating renewable sources [3,5]. In literature enormous number of maximum power 
tracking algorithms like perturb and observe $(\mathrm{P} \& \mathrm{O})$, Incremental conductance, Hill climbing, Fuzzy logic controller, Neural network based controllers are available for both PV and wind system individually, each of the tracking algorithms is having its own advantages and limitations $[6,7]$.

$\mathrm{P} \& \mathrm{O}$ and Hill climbing methods are most common methods used in PV and wind system [3, 6], due to its simple structure and easy to implement. Both the methods sense voltage and current parameters from the renewable energy sources and its works on the principle of perturbation. In $\mathrm{P} \& \mathrm{O}$ MPPT, voltage is the perturbation element and in hill climbing, the duty cycle is the perturbation element. By varying the perturbation element, it calculates the change in power and compares with the previous values for obtaining the maximum power from the source. But it has the limitation in the effective tracking of maximum power point under variable weather condition.

Incremental conductance method is another method used in both PV and wind system [7], due to its ability in handling the non-linearity characteristics to extract maximum power. It senses voltage and current from the renewable energy sources and tracks maximum power by finding the ratio between instantaneous conductance to the incremental conductance. It is less complex and easy to implement compared to the other available MPPTs in literature.

Artificial neural network (ANN) maximum power point tracking (MPPT) method which is fast and precise in finding and tracking the maximum power point (MPP) in photovoltaic (PV) and Wind system applications, under rapidly changing of solar irradiation and wind velocity respectively. ANN and P\&O MPPT algorithms, and other components of the MPPT control system which are PV module, Wind turbine, PMSG and DC-DC boost converter, are simulated in MATLAB-Simulink, and their performances are compared as well. A 570W PV system and 500W Wind system is considered with Boost Converter topology for the design of the hybrid system and it is simulated in MATLAB/Simulink environment to analyze the performance of ANN MPPT. Simulation results show that ANN method has very fast and more precise response under fast changes of solar irradiation and wind velocity.

In section II, the design of hybrid PV and Wind system is presented. In section III, $\mathrm{P} \& \mathrm{O}$ and ANN based MPPT for hybrid system is discussed. In section IV, the simulation results are given, finally, section $\mathrm{V}$, conclusion is presented.

\section{DESIGN OF HYBRID PV AND WIND SYSTEM}

A hybrid renewable energy system is designed by integrating the both PV and wind energy sources with the individually dedicated Boost converters. The basic block diagram topology of the hybrid system is shown in Fig. 1.

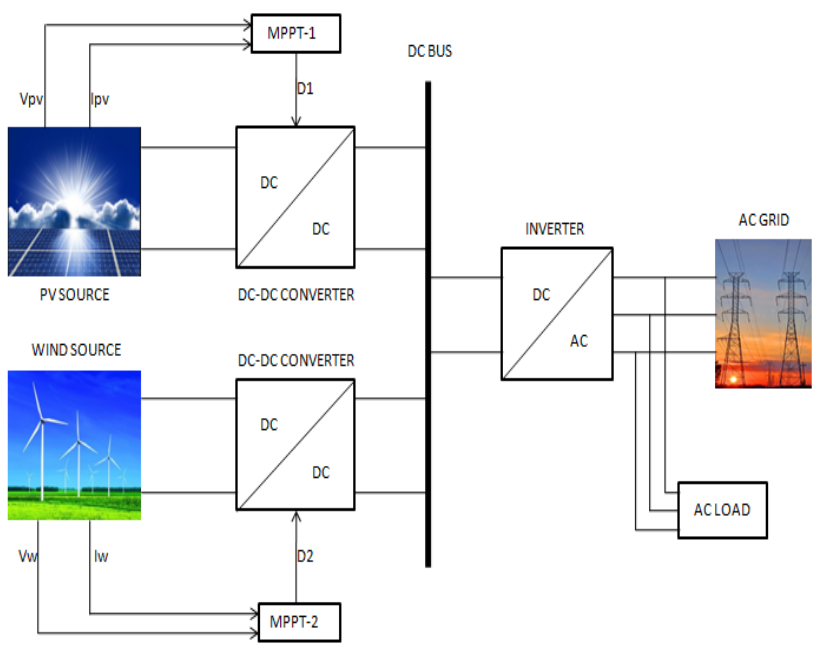

Fig1: Basic topology for hybrid PV and wind system

The PV system is fed to the DC-DC Boost converter and the output of the wind system is rectified by diode bridge rectifier and then fed to the DC-DC converter. Both the sources are integrated together at the common DC link bus capacitor to make a hybrid system. The modeling of PV system, wind system and design of basic Boost converter is presented in following subsections.

\section{A. PV system}

The design of PV model for making hybrid renewable energy system is presented in this subsection. The mathematical modeling of the PV system is derived from the basic $I_{P V}-V_{P V}$ characteristics of PV panel [7].

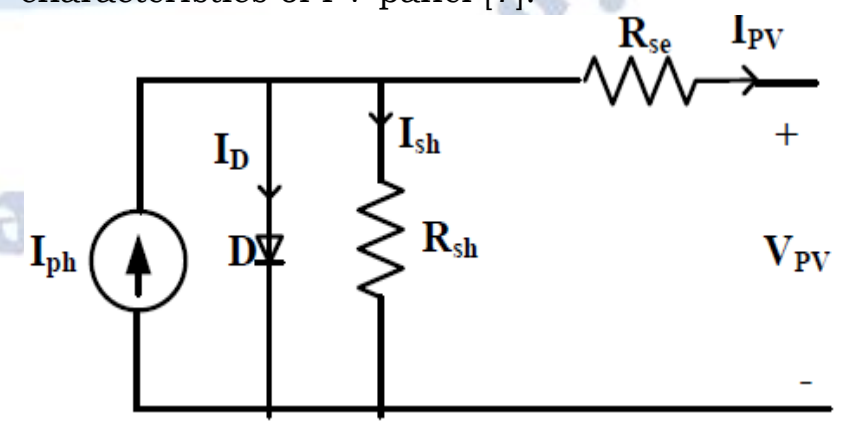

Fig.2: PV cell single diode model equivalent circuit.

The PV panel output voltage $\left(\mathrm{V}_{\mathrm{PV}}\right)$ and current $\left(\mathrm{I}_{\mathrm{PV}}\right)$ are derived from the basic equations Eq. (1) and (2) [3]. 
$\mathrm{V}_{\mathrm{PV}}=\frac{\eta K T}{q} \ln \left[\frac{I_{p h}}{I_{P v}}+1\right]$

$I_{P v}=I_{p h}-I_{p v r s c}\left[e^{\frac{q\left(V_{p v}+I_{p v} R_{S}\right)}{\eta K T}}-1\right]-\frac{V_{P v}+I_{p v} R_{s e}}{R_{s h}}$

$\mathrm{V}_{\mathrm{PV}}$ is $\mathrm{PV}$ panel output voltage $(\mathrm{V}), \mathrm{R}_{\mathrm{sh}}$ is Shunt resistance of single diode model $(\Omega), I_{p h}$ is PV Cell phase current (A), $R_{\text {se }}$ is Series resistance of single diode model $(\Omega), \eta$ is Ideality factor, $q$ is Electron charge $\left(1.60217^{*} 10^{-19} \mathrm{C}\right), \mathrm{K}$ is Boltzman constant pf PV panel $\left(1.38 * 10^{-23} \mathrm{~J} / \mathrm{K}\right), \mathrm{T}$ is Ambient temperature $(\mathrm{K}), \mathrm{I}_{\mathrm{pv}}$ is PV panel output current $(\mathrm{A})$, $\mathrm{I}_{\text {Pvrsc }}$ is Reverse saturation current of PV panel (A).

A hybrid renewable energy system is designed by considering $570 \mathrm{~W}$ PV systems and its design specification of BP Solar SX3190 PV module is listed in the Table. I.

Table I: Parameter specification of BP Solar SX3190 PV module

\begin{tabular}{|l|l|}
\hline \multicolumn{1}{|c|}{ Parameter Description } & \multicolumn{1}{c|}{ Rating } \\
\hline Maximum power $\left(\mathrm{P}_{\mathrm{MP}}\right)$ & $190 \mathrm{~W}$ \\
\hline Maximum Current $\left(\mathrm{I}_{\mathrm{MP}}\right)$ & $7.82 \mathrm{~A}$ \\
\hline Maximum Voltage $\left(\mathrm{V}_{\mathrm{MP}}\right)$ & $24.3 \mathrm{~V}$ \\
\hline Short circuit current $\left(\mathrm{I}_{\mathrm{SC}}\right)$ & $8.5 \mathrm{~A}$ \\
\hline Temperature $(\mathrm{T})$ & $25^{\circ} \mathrm{C}$ \\
\hline Open circuit voltage $\left(\mathrm{V}_{\mathrm{oc}}\right)$ & $30.6 \mathrm{~V}$ \\
\hline Parallel strings & 3 \\
\hline Series-connected modules per string & 1 \\
\hline Solar irradiation $(\mathrm{G})$ & $1000 \mathrm{~W} / \mathrm{m}^{2}$ \\
\hline
\end{tabular}

Based on the availability of solar irradiation, the corresponding I-V and $\mathrm{P}-\mathrm{V}$ characteristics for $\mathrm{BP}$ SX3190 PV module are shown in Fig.3. It is observed that the generated PV maximum output power will depend on the availability of solar irradiations.
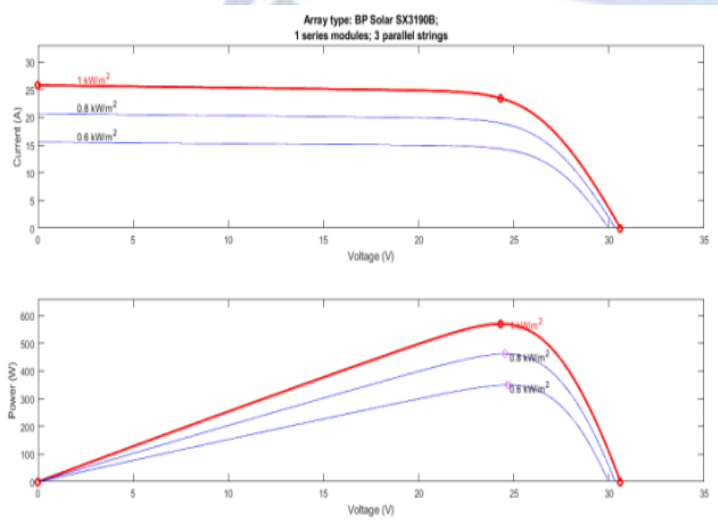

Fig.3: I-V and P-V characteristics for BP SX3190 PV module

\section{B. Wind system}

The power available in a wind stream $\mathrm{P}_{\text {air }}$ is given by [5]:

$\mathrm{P}_{\mathrm{air}}=\frac{1}{2} \rho A V_{W}^{3}$

Where $\mathrm{P}_{\text {air }}$ is the power available from the wind [W], $\rho$ is the air density $\left[\mathrm{kg} / \mathrm{m}^{3}\right], A$ is the cross-sectional area of the stream $\left[\mathrm{m}^{2}\right]$ and $\mathrm{V}_{\mathrm{w}}$ is the free wind velocity $[\mathrm{m} / \mathrm{s}]$. This power cannot be completely extracted and the conversion efficiency is dependent on the power coefficient $\mathrm{C}_{\mathrm{P}}$. The power coefficient expresses the ratio between the extracted power $\mathrm{P}_{\mathrm{w}}$ and the available power $\mathrm{P}_{\text {air }}$ as defined by:

$\mathrm{C}_{\mathrm{P}}=\frac{P_{w}}{P_{\text {air }}}$

$\mathrm{C}_{\mathrm{P}}$ can have a maximum of 0.593 , known as the Betz limit. It is a function of two variables: the blade pitch angle $\beta$ and the tip speed ratio $\lambda$. In addition, it is well known that $\lambda$ is defined as:

$$
\lambda=\frac{w_{r o t}}{V_{w}} R
$$

Where $\mathrm{R}$ is the radius of the rotor $[\mathrm{m}]$ and $\omega_{\text {rot }}$ is the rotational speed of the rotor $[\mathrm{rad} / \mathrm{s}]$. Hence, the power extracted by the rotor of a wind turbine is given by

$$
\mathrm{P}_{\mathrm{w}}=\frac{1}{2} \rho A V_{W}^{3} C_{P}(\beta, \lambda)
$$

The Aeolos-H 500W wind turbine is considered for hybrid system design and the design specifications are listed in Table II.

\section{Table II: Wind system Parameter}

\begin{tabular}{|l|l|}
\hline \multicolumn{1}{|c|}{ Parameter Description } & \multicolumn{1}{c|}{ Rating } \\
\hline Power $(\mathrm{P})$ & $500 \mathrm{~W}$ \\
\hline Impedance $\left(\mathrm{R}_{\mathrm{a}}\right)$ & $0.775 \Omega$ \\
\hline Inductance $\left(\mathrm{L}_{\mathrm{q}}\right.$ and $\left.\mathrm{L}_{\mathrm{d}}\right)$ & $7.31 \mathrm{mH}$ \\
\hline Magnetizing flux $\left(\varnothing_{\mathrm{m}}\right)$ & $0.37387 \mathrm{wb}$ \\
\hline Pair of Poles $\left(\mathrm{P}_{\mathrm{P}}\right)$ & 2 \\
\hline Torque $/$ Current $(\mathrm{T} / \mathrm{A})$ & $1.1216 \mathrm{Nm} / \mathrm{A}$ \\
\hline Cut-in wind speed & $4 \mathrm{~m} / \mathrm{s}$ \\
\hline Moment of inertia $(\mathrm{J})$ & $0.00126811 \mathrm{~kg} / \mathrm{m} 2$ \\
\hline Rated wind speed & $12 \mathrm{~m} / \mathrm{s}$ \\
\hline
\end{tabular}

The characteristics of the wind turbine power generation system at different wind velocity are shown in Fig.4 


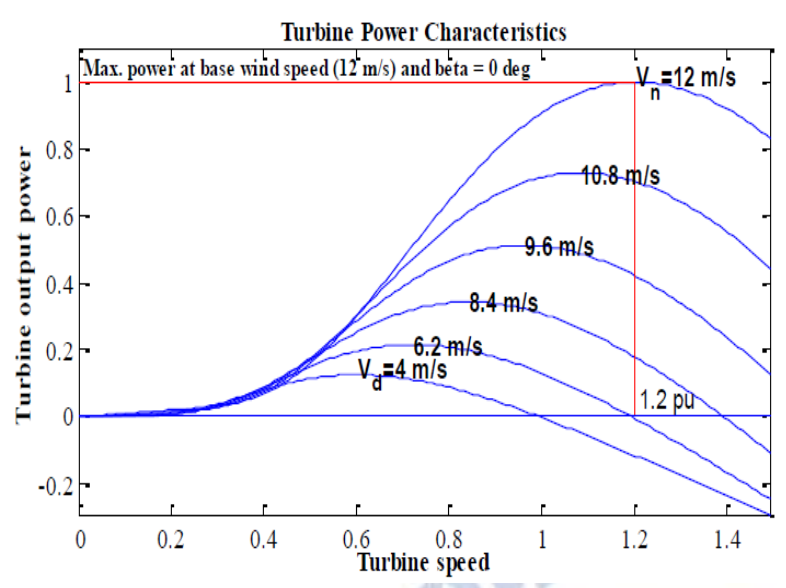

Fig.4: Aeolos-H 500W Wind turbine power characteristics

\section{DC-DC Boost converter}

It consists of the single semiconductor switch $\left(\mathrm{S}_{1}\right)$, a single diode $\left(\mathrm{D}_{1}\right)$, two energy storage elements inductor $\left(\mathrm{L}_{1}\right)$ and capacitor $\left(\mathrm{C}_{1}\right)$ as shown in Fig. 5 for each source [7]. Its output voltage is always much higher than the input source voltage

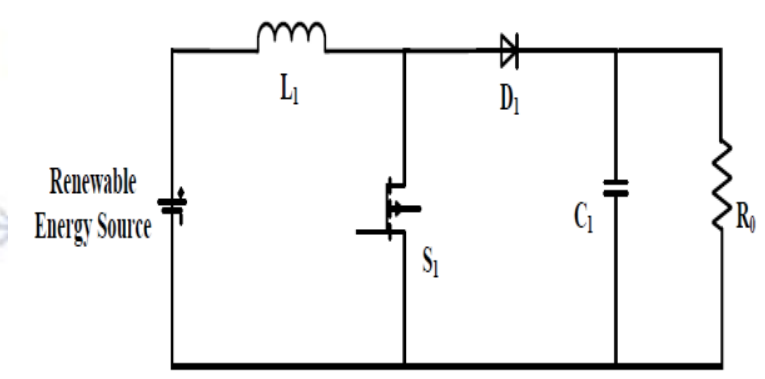

Fig.5: Boost converter circuit

Table III: Parameter specification of Boost converter

\begin{tabular}{|l|l|}
\hline \multicolumn{1}{|c|}{ Description } & \multicolumn{1}{c|}{ Rating } \\
\hline Input Voltage & $\mathrm{V}_{\text {in }}=24 \mathrm{~V}$ \\
\hline Output voltage & $\mathrm{V}_{\text {out }}=230 \mathrm{~V}$ \\
\hline Inductor & $\mathrm{L}=15.3 \mathrm{mH}$ \\
\hline DC link capacitor & $\mathrm{C}=4.8 \mu \mathrm{F}$ \\
\hline Load resistance & $\mathrm{R}=92.8 \Omega$ \\
\hline Switching frequency & $\mathrm{f}_{\mathrm{s}}=20 \mathrm{KHZ}$ \\
\hline
\end{tabular}

\section{IMPLEMENTATION OF P\&O AND ANN MPPT}

\section{A. Perturb and Observe method}

Each and every MPPT algorithm has its own advantages and disadvantages. Perturb and observe $(\mathrm{P} \& \mathrm{O})$ method is widely used due its simplicity. In this algorithm we introduce a perturbation in the operating voltage of the panel and wind rectifier. Perturbation in voltage can be done by altering the value of duty-cycle of dc-dc converter.

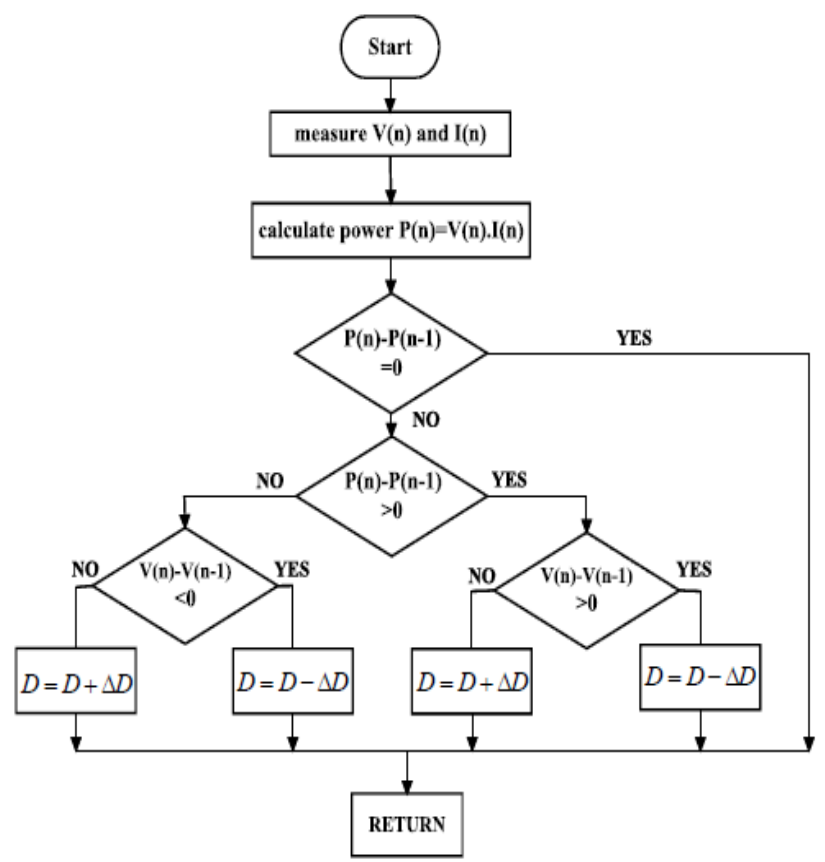

Fig.6: The flowchart of perturb and observe $(\mathrm{P} \& \mathrm{O})$ MPPT technique

As we can see from the flow chart first of all we measure voltage and current $\left(\mathrm{V}_{\mathrm{PV}}, \mathrm{I}_{\mathrm{PV}}, \mathrm{V}_{\mathrm{WIND}}\right.$ and I WIND) by using these values we calculate power, calculated power is compared with previous one and accordingly we increase or decrease the voltage to locate the Maximum Power Point by altering the duty cycle of converter.

\section{B. Neural Networks}

A neural network is inspired by biological neural networks as like a brain. Human brain learns from experience and information's are stored as patterns. The information storage process in terms of patterns has a new computing field. This computing uses a massive network and is trained to solve a specific problem.

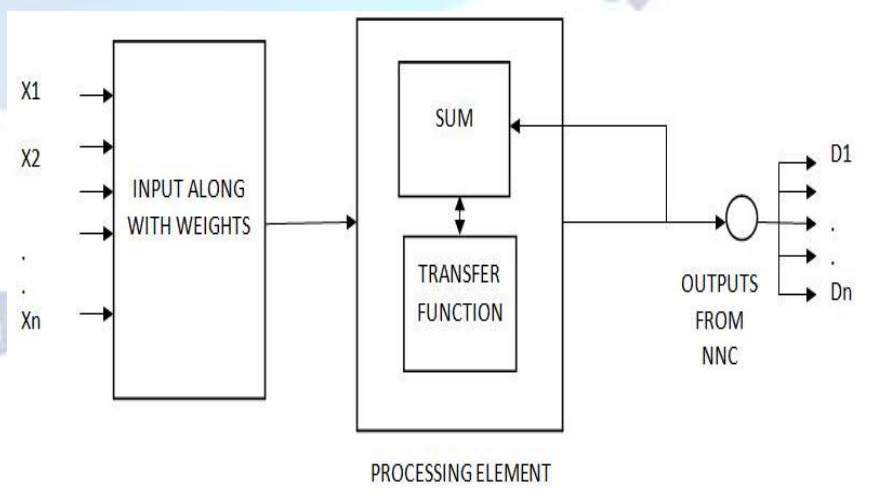

Fig.7: Artificial Neural Network Layout

A set of artificial neurons have been interconnected to form the neural network, and it processes the information using a connectivity approach for 
computation. All artificial neural networks exhibit the same structure. In this, some neurons interfere to receive input, other neurons interfere with the network output and rest of the neuron has a role but will not be displayed. Basically, the neural network has input layer, output layer and the hidden layer. The existence of hidden layer depends on the application. This neural network for MPPT has three layers, namely input layer, hidden layer and output layer.

\section{Training and Artificial Neural Network}

After framing the network for a particular application the next step is training the artificial neural network. This process involves the random assumption of initial weights. Artificial neural network training can be approached in two ways namely supervised and unsupervised. The output is known in supervised training and therefore input is given as per the required output. This process involves the comparison of resulting output and desired output so that error value would be generated. The error value so obtained is propagating back and weights are adjusted and this process continues until desired output is obtained. The set of data which enable this whole process is called "training set". On other unsupervised training will be preceded by the random input as desired output is not predictable. So this process is also called as self-organization.

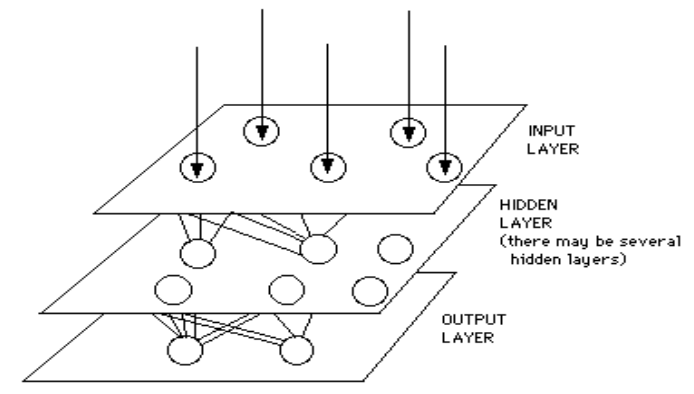

Fig.8: Layer arrangement in a neural network

\section{Components of Artificial Neural Network}

There are seven major components involved in the artificial neural network. These components are important whether the neuron is used in input, output or hidden layer.

1. Determination of weight

2. Summation function

3. Transfer function

4. Scaling and limiting

5. Output function

6. Error function and back propagated value

7. Learning function
In this paper for tracking maximum power point, an artificial neural network is used for both sources. A three layer neural network is used to reach MPP. $V_{P V}$ and $I_{P V}$ are two input variables and Duty cycle 1 is the output variable of ANN for solar system. $V_{\text {WIND }}$ and IWIND are two input variables and Duty cycle 2 is the output variable of ANN for Wind system. It is necessary to obtain some data as input and output variable to train the neural network (both systems). There are several methods to train ANN. In this paper error back propagation method is used to train the ANN. After training the ANN and specification of neuron weights, for any V and I as inputs of ANN, output of ANN is the Duty cycle.

\section{SIMULATION RESULTS}

\section{A. PV system}

A BP Solar SX3190 PV Module has been used for the construction of hybrid renewable energy system. The basic PV system with Boost converter along with $\mathrm{P} \& \mathrm{O}$ and ANN MPPT control algorithm is implemented in MATLAB/Simulink model as shown in Fig. 9, 10. The inputs to the $\mathrm{P} \& \mathrm{O}$ and ANN MPPT controller are $V_{P V}$ and $I_{P V}$ and it gives the corresponding variable duty cycle to extract maximum available power from the renewable PV source.

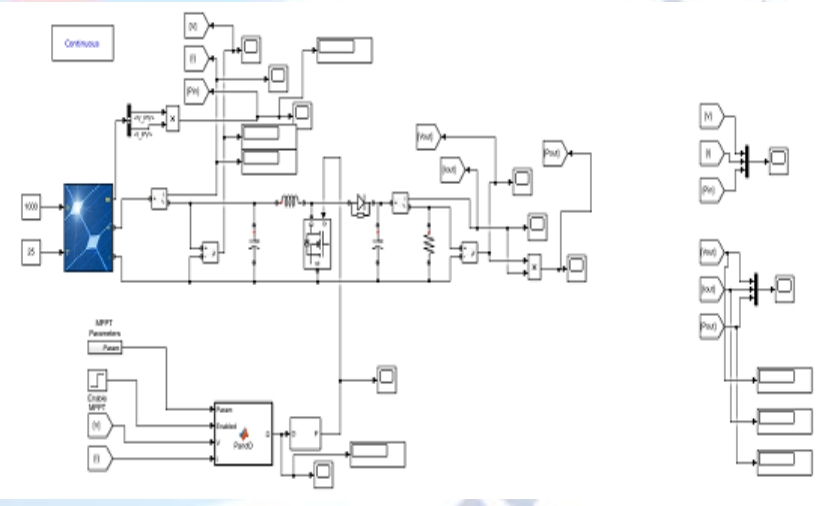

Fig.9. Simulation of PV system with boost converter and P\&O MPPT

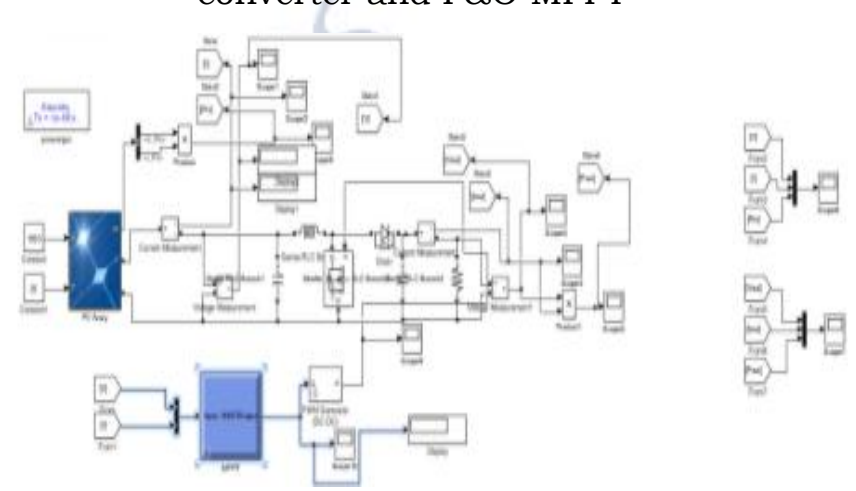

Fig. 10. Simulation of PV system with boost converter and ANN MPPT 


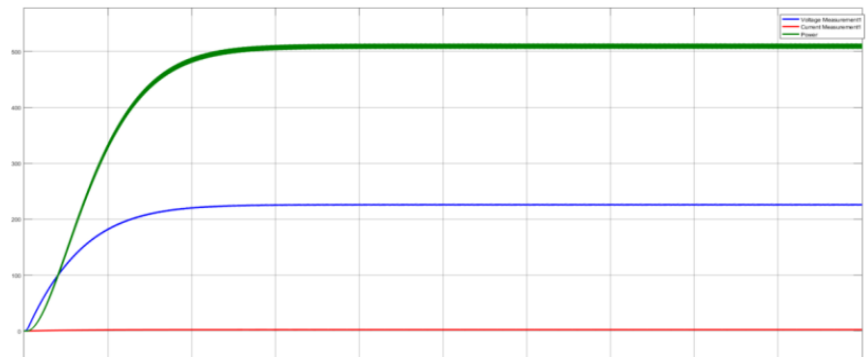

Fig. 11: Boost converter output voltage, current and

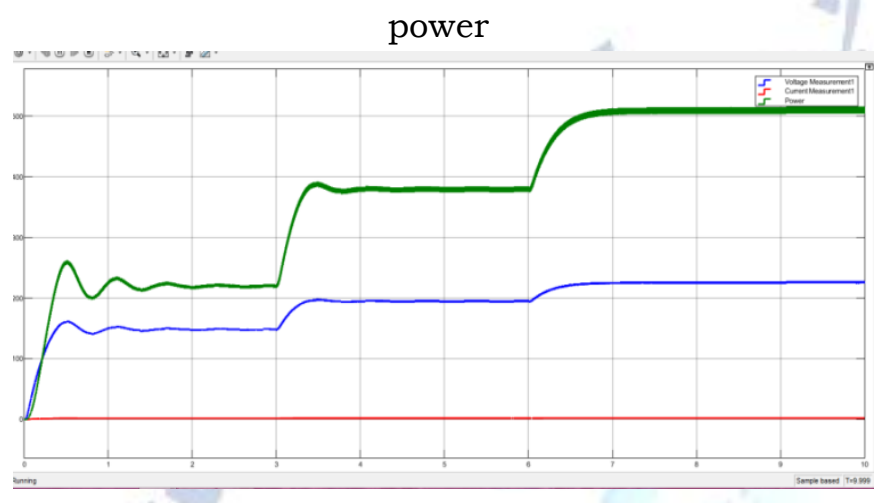

Fig. 12: Boost converter output voltage, current and power at different irradiation levels.

\section{B. Wind system}

A $500 \mathrm{~W}$ wind system is implemented in Matlab/Simulink model with P\&O and ANN MPPT control algorithm as shown in Fig. 13, 14. It takes $\mathrm{V}_{\mathrm{W}}$ and $\mathrm{I}_{\mathrm{W}}$ as input variables for $\mathrm{P} \& \mathrm{O}$ and $A N N$ MPPT system and produces the corresponding variable duty cycle for obtaining the maximum power from the renewable wind energy source.

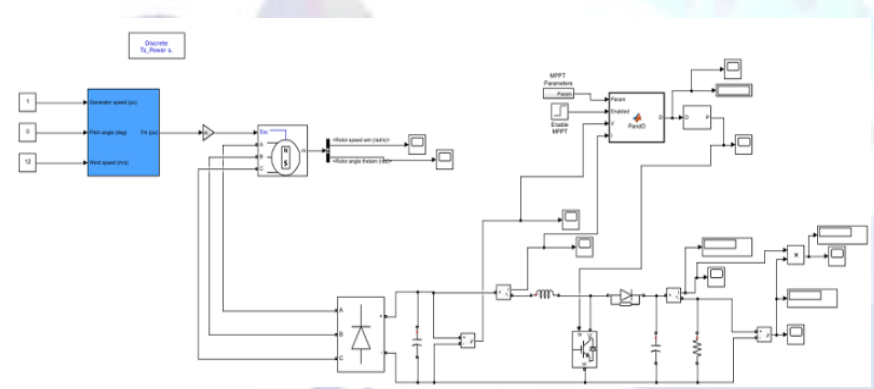

Fig. 13: Simulation of Wind system with boost converter and P\&O MPPT

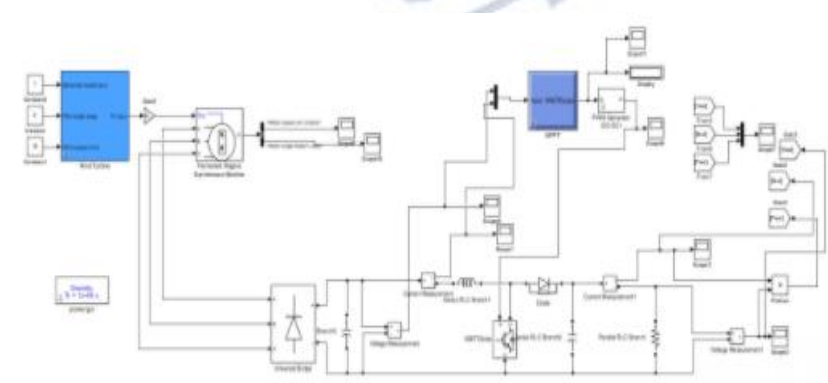

Fig. 14: Simulation of Wind system with boost converter and ANN MPPT

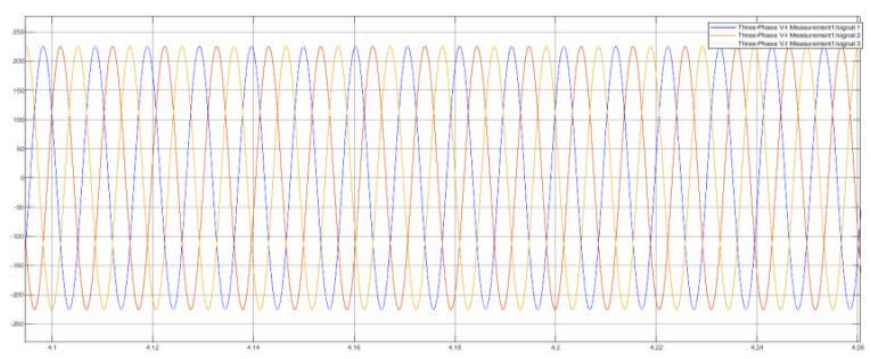

Fig. 15: PMSG voltage

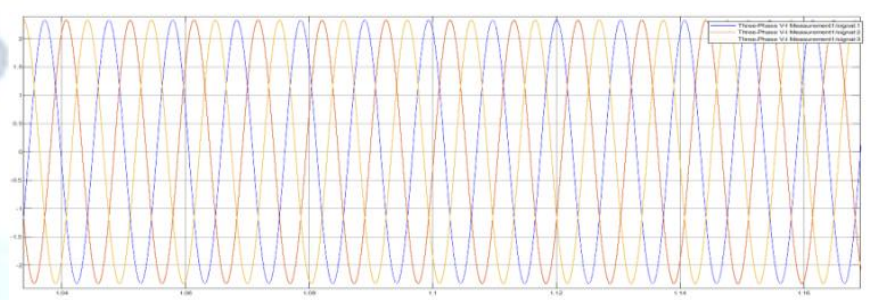

Fig. 16: PMSG Current

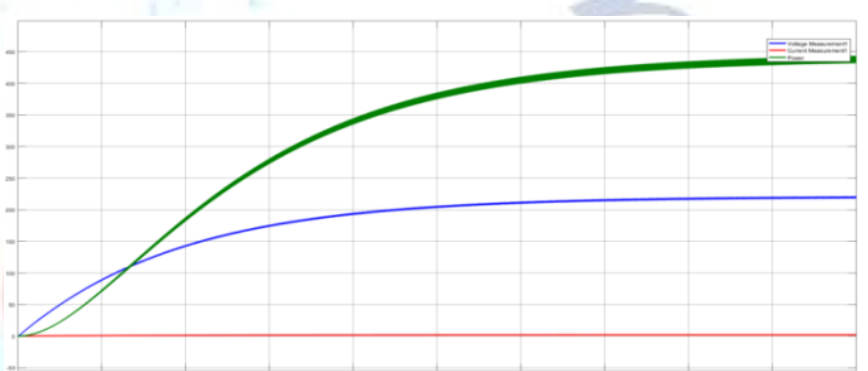

Fig. 17: Boost converter output voltage, current and power

\section{Hybrid system}

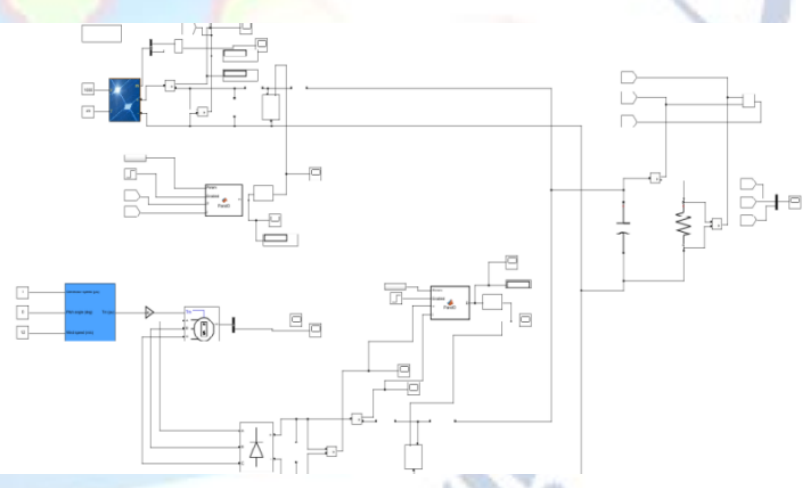

Fig. 18: Simulation of Hybrid system with Boost converter and $\mathrm{P} \& \mathrm{O}$ MPPT

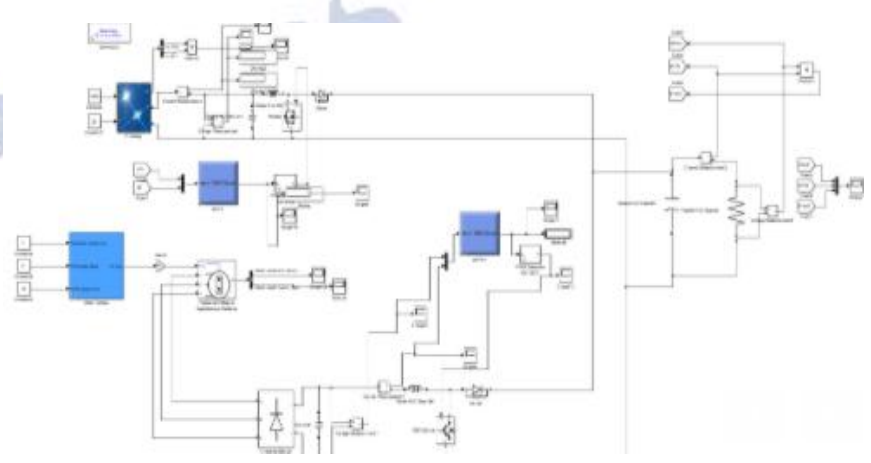

Fig. 19: Simulation of Hybrid system with Boost converter and ANN MPPT 


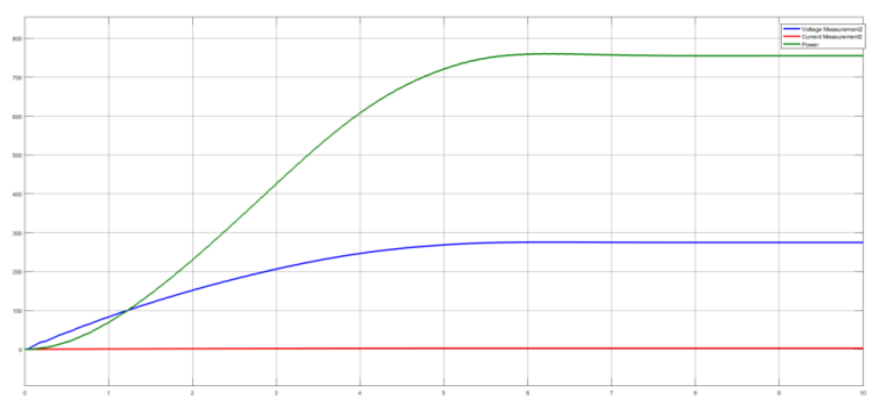

Fig.20: Hybrid system DC bus output voltage, current and power

Table IV: Comparative analysis of hybrid PV and wind system with different MPPT techniques

\begin{tabular}{|l|c|c|c|c|}
\hline & \multicolumn{2}{|c|}{$\begin{array}{c}\text { P\&O BASED } \\
\text { MPPT }\end{array}$} & \multicolumn{2}{c|}{$\begin{array}{c}\text { ANN BASED } \\
\text { MPPT }\end{array}$} \\
\hline $\begin{array}{l}\text { Input solar } \\
\text { irradiations } \\
\text { (W/m2) }\end{array}$ & $\begin{array}{c}800 \\
\mathrm{~W} / \mathrm{m} 2\end{array}$ & $\begin{array}{c}1000 \\
\mathrm{~W} / \mathrm{m} 2\end{array}$ & $\begin{array}{c}800 \\
\mathrm{~W} / \mathrm{m} 2\end{array}$ & $\begin{array}{c}1000 \\
\mathrm{~W} / \mathrm{m} 2\end{array}$ \\
\hline $\begin{array}{l}\text { Input wind } \\
\text { velocity } \\
\text { (m/s) }\end{array}$ & $\begin{array}{c}11 \\
\mathrm{~m} / \mathrm{s}\end{array}$ & $\begin{array}{c}12 \\
\mathrm{~m} / \mathrm{s}\end{array}$ & $\begin{array}{c}11 \\
\mathrm{~m} / \mathrm{s}\end{array}$ & $\begin{array}{c}12 \\
\mathrm{~m} / \mathrm{s}\end{array}$ \\
\hline Voltage(V) & 218 & 228.4 & 223 & 230 \\
\hline Current(A) & 3.27 & 3.32 & 3.36 & 3.4 \\
\hline Power(W) & 711.7 & 758 & 748.9 & 780 \\
\hline
\end{tabular}

\section{CONCLUSION}

The various MPPT methods available in the literature for extracting maximum power in the hybrid system are discussed. The modified single P\&O MPPT control algorithm is implemented in hybrid renewable energy system consists of $570 \mathrm{~W}$ PV system and $500 \mathrm{~W}$ wind system with a basic Boost converter to track maximum power from both sources. The performance of the ANN MPPT is analyzed by considering the change in solar irradiations and wind speed. The obtained results are compared with the P\&O MPPT technique, which reveals ANN based MPPT, gives the best result. The ANN MPPT effectively tracks the maximum power from both sources.

\section{REFERENCES}

[1] G.B. Gharehpetian, S. Mohammad Mousavi Agah, "Distributed Generation Systems," Elsevier, 2017.

[2] Cumulative development of various renewable energy system/devices in country, Retrieved from http://mnre.gov.in/mission-and-vision-2/achievents.

[3] S. Saravanan, N. Ramesh Babu, "RBFN based MPPT algorithm for PV system with high step up converter," Elsevier, May. 2016.

[4] Damodhar Reddy, Sudha RAMASAMY, "Single Stage Energy Conversion through RBFN Controller based Boost Type Vienna Rectifier for Wind Turbine System , " Journal of Science, 2017.
[5] Daniel Zammit, Cyril Spiteri Staines, Alexander Micallef, Maurice Apap and John Licari, "Incremental Current Based MPPT for a PMSG Micro Wind Turbine in a Grid-Connected DC Microgrid”, Elsevier, ICAE2017, 2017.

[6] Ramadoni Syahputra, Indah Soesanti, "Performance Improvement for small-scale Wind Turbine system based on Maximum Power Point Tracking Control", energies, October 2019.

[7] K. Kumar, N. Ramesh Babu, K.R Prabhu, "Design and Analysis of Modified Single P\&O MPPT Control Algorithm for a Standalone Hybrid Solar and Wind Energy Conversion System," Journal of Science, 2017.

[8] Rashid M.H., Power Electronics: Circuits. Devices \& Applications, Pearson Education (2014). 